http://e-journal.stit-islamic-village.ac.id/index.php/JECIES

\title{
PENINGKATAN KEMAMPUAN MENULIS MELALUI PERMAINAN MENGGAMBAR (PENELITIAN TINDAKAN DI KELOMPOK B TAMAN KANAK- KANAK SOS DESA TARUNA JAKARTA TIMUR)
}

\author{
Ambar Pawitri \\ STKIP Kusuma Negara \\ Email: ambarprawitri@stkipkusumanegara.ac.id \\ Received: 25 Juli, 2020. \\ Accepted: 19 Agustus, 2020. \\ Published: 30 September, 2020
}

\begin{abstract}
The aims of this research are to know the ability to write in eary childhood through drawing games. The research was conducted through action research in group B kindergarten SOS Desa Taruna. The study is conducted using action research, and held on May to June second semester. The procedures for this action research are following Kemmis and Taggart's model consisting of four phases ycle which are (a) planning, (b) action, (c) observation, (d) reflection. Data analysis is carried using both quantitative and qualitative by positive respons of drawing games. The $1^{\text {st }}$ cycle, early childhood writing ability is...\% and early childhood writing ability increasing...\% in the $2^{\text {nd }}$ cycle. The implication of the research finding, drawing game should be children learn writing ability with fun but can make children study writing, drawing game it should be alternative to teach writing for the children.
\end{abstract}

Keywords: Writing ability, drawing game, and action research

\begin{abstract}
ABSTRAK
Penelitian ini bertujuan memperolah data mengenai cara meningkatkan kemampuan menulis melalui permainan menggambar pada anak usia dini. Penelitain ini dilakukan melalui penelitian tindakan di Kelompok B TK SOS Desa Taruna Jakarta Timur, pada bulan Mei sampai Juni, semester dua. Prosedur penelitian menggunakan model Kemmis dan Mc Taggart yang terdiri dari 4 (empat) tahap yaitu (a) perencanaan; (b) pelaksanaan; (c) observasi; (d) refleksi. Analisis data dilakukan dengan menggunakan analisis kuantitatif dan analisis kualitatif. Hasil penelitian menunjuk.kan bahwa terjadi peningkatan kemampuan menulis anak usia dni setelah mengikuti pembelajaran dengan pendekatan melalui permainan menggambar. Tingkat penguasaan menulis pada siklus 1 sebesar 64.4\%., meningkat menjadi 88.73\%.setelah mengikuti siklus 2. Implikasi dari penelitian ini adalah permainan menggambar dapat membuat anak belajar menulis dengan menyenangkan akan tetapi anak tetap belajar menulis, menggambar juga menjadi alternative guru untuk mengajarkan menulis kepada anak.
\end{abstract}

Kata kunci: Kemampuan menulis, permainan menggambar, penelitian tindakan 


\section{PENDAHULUAN}

Pendidikan adalah hak warga negara, tidak terkecuali pendidikan di usia dini merupakan hak warga negara dalam mengembangkan potensinya sejak dini. Berdasarkan berbagai penelitian bahwa usia dini merupakan pondasi terbaik dalam mengembangkan kehidupannya di masa depan. Selain itu pendidikan di usia dini dapat mengoptimalkan kemampuan dasar anak dalam menerima proses pendidikan di usia-usia berikutnya.

Peningkatan kualitas anak usia dini dirasakan makin mendesak dan perlu, mengingat optimalisasi kualitas manusia harus memiliki dasar-dasar yang kuat sejak dari awal kehidupan. Penelantaran pada saat yang kritis ini akan merugikan pertumbuhan dan perkembangan anak. Perhatian terhadap anak menjadi sangat penting, bukan hanya mereka adalah harapan dan masa depan bangsa, melainkan juga karena eksistensi, posisi dan potensi mereka yang patut dikembangkan sebagai sebuah asset sumber daya manusia yang tak ternilai harganya. Anak merupakan "lahan subur" untuk menanamkan nilainilai agama, nilai-nilai budaya, ilmu pengetahuan, keterampilan dan pengalaman yang kelak akan dipetik hasilnya di masa yang akan datang.

Undang-undang Nomor 20 Tahun 2003 tentang Sistem Pendidikan Nasional Pasal 1 ayat 14 menyatakan bahwa Pendidikan Anak Usia Dini (PAUD) adalah suatu upaya pembinaan yang ditujukan kepada anak sejak lahir sampai dengan usia enam tahun yang dilakukan melalui pemberian rangsangan pendidikan untuk membantu pertumbuhan dan perkembangan jasmani dan rohani agar anak memiliki kesiapan dalam memasuki pendidikan lebih lanjut.(Sistem Pendidikan Nasional, 2003)

Masa usia dini merupakan masa keemasan (golden age) dimana stimulasi seluruh aspek perkembangan berperan penting untuk tugas perkembangan selanjutnya. Pada masa ini pertumbuhan otak berlangsung sangat pesat (eksplosif). Perkembangan pada tahun-tahun pertama sangat penting menentukan kualitas anak di masa depan. Dalam lingkungan yang aman dan berbagai kegiatan yang bersifat sensor motorik, anak menyerap berbagai pengalaman sebagai hasil interaksinya dengan lingkungan sekitar seperti spons yang menyerap air. Lingkungan menjadi salah satu faktor yang mempengaruhi perkembangan anak. Pendidikan usia dini harus membantu perkembangan anak, sehingga kurikulum yang diatur sebaiknya berhubungan dengan pekerjaan, kesenian, keahlian, pembangunan melalui nyanyian, permainan, bahasa dan matematika. Prinsip belajar melalui bermain dapat menimbulkan kreativitas, inilah prinsip yang perlu ditanamkan pada anak usia dini.(Santoso, 2002)

Berbagai penelitian menunjukkan bahwa bermain memungkinkan anak bergerak secara bebas sehingga anak mampu mengembangkan kemampuan motoriknya. Pada saat bermain anak berlatih menyesuaikan 
antara pikiran dan gerakan menjadi suatu keseimbangan. (Santoso, 2005) Bermain bagi anak merupakan suatu kebutuhan. Hasil penelitian Universitas Indonesia (1981) menunjukkan bahwa anak yang waktunya lebih banyak tersita untuk belajar "formal" lebih pintar di TK dan kelas 1,2,3. Setelah itu, ia menjadi tidak pintar lagi di kelas yang lebih tinggi. Sebaliknya anak yang kebutuhan bermainnya terpenuhi, makin tumbuh dengan memiliki keterampilan mental yang lebih tinggi, sehingga menjadi lebih mandiri. Ini membuktikan bahwa bermain sebagai suatu kebutuhan anak dan itu penting untuk perkembangan selanjutnya.(Yus, 2011)

Karakteristik anak adalah ceria dan aktif bergerak. Hal ini sesuai dengan pendekatan dan prinsip pendidikan atau pembelajaran pada anak usia dini antara lain adalah sebagai berikut: (1) konsep belajar sambil bermain; (2) kedekatan dengan lingkungan; (3) alam sebagai sarana pembelajran; (4) anak belajar melalui panca inderanya; (5) konsep kecakapan hidup; (6) anak sebagai pembelajaran aktif; (7) pendidik wajib dekat dengan anak dengan penuh kasih sayang; (8) etika dan estetika perlu diberikan secara sederhana.(Santoso, 2010) Agar anak usia dini dapat berkembang seluruh aspek perkembangannya maka dapat melakukan beberapa hal seperti memberikan rangsangan visual, memberikan rangsangan verbal, memberikan rangsangan afektif (pelukan, ciuman, elusan), memberikan rangsangan fisik (melatih menggenggam, melempar, meloncat, memanjat, memeras, bersiul, melatih ekspresi muka), memberikan latihan bersosialisasi dan berkomunikasi (mau digendong orang lain, mau ditegur, ikut bermain, dan lain sebagainya).

Dngan kata lain dengan bermain anak pun belajar, namun bermain dipandang sebaliknya yakni sebagai aktivitas tak produktif. Padahal baik belajar maupun bermain merupakan aktivitas yang sangat melengkapi dalam kehidupan anak-anak.

Mempersiapkan kemampuan menulis pada anak diawali dengan kemampuannya mencoret yang abstrak bertahap menjadi jelas bentuk hurufnya. Anak melakukan aktivitas mencoret lewat keterampilan tangannya, dimulai dari goresan tak beraturan dengan spidol, pensil warna atau alat tulis lainnya. Tidak sedikit orang tua berkeberatan bila anaknya melakukan kagiatan coret mencoret. Salah satu alasannya adalah rumah menjadi kotor, tidak rapi akibat coretan anak dimana-mana, padahal mencoret merupakan langkah persiapan bagi kemampuan menulis anak di usia dini. Dengan mencoret, anak melatih motorik halus otot jari dan tangan. Orangtua diharapkan tidak banyak mengkritik produk tulisan anak, melainkan memberikan reward, misalnya berupa pujian atas usaha dan kesabaran anak. Seiring dengan kematangan dan perkembangan usianya, anak akan semakin terampil dalam menulis. 
Pada usia 5 atau 6 tahun, koordinasi gerakan motorik halus berkembang pesat. Pada masa ini anak mampu mengkoordinasikan gerakan visual motorik, seperti mengkoordinasikan gerakan mata dengan tangan, lengan dan tubuh secara bersamaan, antara lain dapat dilihat saat anak menggunting, menempel,menulis, atau menggambar dan mewarnai. Kemudian menurut Suyadi, pada usia 6 tahun muncul keterampilan menolong diri sendiri yang akan mencapai puncak kesempurnaan. Ketercapaian semua gerakan tidak lepas dari perhatian jangka panjang yang diperagakan olehnya, mulai dari gerakan-gerakan tangan dan gerakan-gerakan lainnya yang saling terkait. (Suyadi, 2010)

Kemampuan menulis pada anak usia dini muncul ditandai oleh berbagai tahapan, seperti senang bertanya, dan memberikan informasi tentang suatu hal, anak sedang mencoret-coret dinding, buku, atau pasir.. Jika kemampuan tersebut tidak dikembangkan dengan baik maka potensi tersebut akan hilang atau tidak terstimulasi. Dengan demikian TK sebagai lembaga peletak pondasi dasar dapat memberikan kontribusi positif dalam mengembangkan kemampuan menulis permulaan sesuai dengan prinsip belajar seraya bermain.

Pengembangan kemampuan menulis awal di Taman Kanak-kanak khususnya anak usia 5-6 tahun harus menyenangkan dan menarik bagi anak dan disini peranan seorang guru sangatlah besar, yaitu menciptakan berbagai aktivitas bermain sederhana yang memberikan arahan dan bimbingan agar berbagai potensi yang tampak akan tumbuh berkembang secara optimal. Kegiatan menulis tidak boleh menjadi beban, anak harus dapat menikmati kegiatan tersebut, yaitu dengan cara bermain. Bermain memiliki nilai yang tinggi bagi anak dan menjadi syarat mutlak dalam pembelajaran.

Berdasarkan hasil pengamatan peneliti di TK SOS Desa Taruna, anak usia 5-6 tahun khususnya yang berada di kelompok B masih banyak anak yang belum bisa memegang pensil dengan benar. Selain itu terdapat beberapa anak yang gerakan tangannya masih terlihat kaku dalam menulis. Dan masih banyak anak yang belum bisa membuat bentuk-bentuk atau simbol-simbol sederhana, menulis angka, huruf dan kata, serta belum bisa menuliskan nama depan anak sendiri.

Permasalahan tersebut terjadi karena beberapa sebab antara lain yaitu perkembangan motorik halus anak belum berkembang secara optimal, keterbatasan media pembelajaran dan kurang relevan dengan tujuan pembelajaran khususnya dalam meningkatkan kemampuan menulis anak kemudian metode dan strategi yang digunakan belum bervariasi dalam proses pembelajaran serta masih kurangnya kreativitas guru dalam penyediaan sarana pembelajaran yang menunjang aktivitas jari dan tangan anak. Selain itu minimnya pengetahuan guru untuk merancang kegiatan yang terpadu dan 
menarik. Motivasi yang diberikan guru kepada anak dalam melaksanakan masih terkesan menggunakan metode drill yang mengakibatkan kejenuhan dan anak menjadi memiliki beban belajar yang berlebihan. Pengajaran melalui drill dan dikte yang ketat tidak diperkenankan diberikan kepada anak karena cenderung bersifat peniruan tanpa pemahaman.

Mengasah kemampuan menulis seorang anak seharusnya sesuai dengan karakteristik perkembangan anak. Kegiatan bermain merupakan salah satu cara yang dapat diterapkan. Hal ini dijadikan pertimbangan karena dunia anak adalah dunia bermain. Bermain merupakan cara yang paling tepat untuk menstimulasi setiap dimensi perkembangan anak termasuk kemampuan menulis, karena bermain bagi anak adalah kegiatan yang menyenangkan. Jika anak banyak diberikan stimulasi maka anak akan memiliki potensi dalam perkembangan bahasa khususnya menulis dan anak akan memiliki kesiapan saat akan memasuki pendidikan formalnya di Sekolah Dasar.

Berdasarkan masalah yang telah diuraikan di atas, peneliti akan meneliti apakah dengan permainan menggambar, kemampuan menulis anak TK B dapat meningkat. Kegiatan permainan menggambar ini bisa dilakukan dengan beberapa variasi yang dapat memberikan kesenangan dan kepuasan pada anak. Melalui kegiatan tersebut maka akan merangsang kemampuan menulis anak. Adapun kegiatan permainan menggambar nantinya akan sesuai tema yang akan disipakan oleh peneliti. Diharapkan dengan metode permainan menggambar dapat menjadi alternatif pembelajaran yang menyenangkan bagi anak usia dini. Dengan demikian kegiatan tersebut dapat menjadi sumber belajar anak usia 5-6 tahun.

\section{METODE}

Metode penelitian yang digunakan adalah metode penelitian tindakan (Action Research) yang didefinisikan oleh McMillan yang dkutip oleh Mertler bahwa penelitian tindakan sebagai penelitian yang difokuskan pada pemecahan permasalahan kelas atau sekolah khusus, meningkatkan praktik, atau membantu mengambil keputusan di satu situs lokal. Prosedur penelitian ini dilakukan dengan dua siklus. Masing-masing siklus direncanakan dengan pola yang bertahap. Tahapan setiap siklus dilaksanakan melalui proses perencanaan, tindakan, pengamatan dan refleksi.

Metodologi action reseach (penelitian tidakan) ini menggunakan model penelitian tindakan spiral dari Kemmis \& Taggart dengan alasan bahwa model penelitian tersebut merupakan aplikasi nyata dan praktis untuk mendorong perubahan dalam penelitian di bidang pendidikan menjadi lebih baik dan desai ini juga lebih mudah dan sederhana untuk diterapkan di kelas. 


\section{TINJAUAN PUSTAKA}

\section{Hakikat Kemampuan Menulis}

\section{a. Pengertian Kemampuan menulis}

Menulis dapat dipandang sebagai rangkaian aktivitas yang bersifat fleksibel. Seperti halnya perkembangan membaca, perkembangan anak dalam menulis juga terjadi perlahan-lahan. Dalam hal ini anak perlu mendapat bimbingan dalam memahami dan menguasai cara mentransfer pikiran ke dalam tulisan. Belajar menulis anak tidak boleh hanya berpusat pada pembenahan tulisan anak, melainkan pada susunan huruf menjadi kata, dan menyusun kata menjadi kalimat.

Menurut Jackman pengalaman menulis permulaan harus memperkenalkan dan memperkuat sesuatu yang benar dan bermakna untuk anak-anak. (Jackman, n.d.). Dengan begitu anak dapat membiasakan dirinya untuk mengulangi pengalaman menulisnya tersebut secara berulang dan anak akan mengembangkan kemampuannya untuk membuat coretan atau tulisan yang beraneka ragam. Semangat untuk menulis ditumbuhkan dengan memberikan kesempatan pada anak untuk menggambar dan mencoret-coret. Gambar dan coretan anak adalah tulisan pertamanya. Lambat laun seiring dengan perkembangannya, anak akan menulis huruf-huruf.

Seefeldt menyatakan bahwa anak-anak akan menulis dengan menyampaikan pesan dari gambar ke huruf dengan menggunakan tanda gambar tersebut jauh sebelum mereka bisa membentuk bahkan mengenal huruf. (Wasik., 2008).

Selanjutnya menurut Marie Clay ahli keaksaraan New Zealand yang dikutip Beaty, anak-anak menciptakan pengetahuan mereka sendiri tentang menulis, mereka akan mengekstraksi informasi tertentu dari tulisan di sekitar mereka.(Janice J. Beaty, 2010). Jadi anak akan berusaha mengekspresikan diri, perasaan dan pengalaman dalam tulisannya tersebut. Kegiatan menulis yang seperti ini akan terjadi berulang-ulang dengan bentuk yang sama secara terus menerus.

Sementara Whitehurst \& Lonigan yang dikutip Papalia berpendapat pemerolehan keterampilan menulis anak-anak prasekolah adalah mulai menggunakan huruf, angka dan bentukbentuk seperti huruf sebagai simbol yang mewakili kata-kata. (Papalia, Olds, 2009). Anak-anak sering menulis dengan membuat corat-coret pada halaman tengah bukunya dan kemudian membalik atau menulis huruf-huruf lainnya di bagian atas halaman. Lewat pengalaman yang 
berulang, anak-anak akan mengorientasikan huruf cetak ke dalam tulisan mereka.

Menurut Boscolo yang dikutip Siegler, menulis dapat dibagi menjadi dua proses, yaitu penyusunan awal dan perbaikan. Keduanya menuntut penulis mengatasi berbagai tantangan yang antara lain adalah pengaturan tanda baca, ejaan dan tata bahasa kemudian pengaturan yang diperlukan untuk membuat isi yang dipahami dan tujuan dari tulisan, apakah tujuan itu akan membujuk, menjelaskan, atau menyampaikan sudut pandang.(Robert S. Siegler \& Martha Wagner Alibali, 2005) Mampu menulis dan menulis dengan baik merupakan keterampilan penting untuk segala usia.

Pendapat Lamme yang dikutip Sonawat, terdapat beberapa bidang keterampilan yang merupakan prasyarat untuk kemampuan menulis awal: (1) perkembangan otot kecil; (2) koordinasi mata dan tangan; (3) memegang alat tulis. (Reeta Sonawat \& Jasmine Maria Francis, 2007). Kemampuan menulis anak ditandai dengan kemampuan motorik halus dalam memegang pensil atau crayon. Saat anak terbiasa memegang alat tulis, maka kelenturannya dalam membuat coretan akan semakin terlihat.

Perkembangan menulis pada anak usia dini adalah kombinasi dari kedua perkembangan mental dan fisik. Secara mental, anak sedang mengembangkan keterampilan konsentrasi, memori dan bahasa. Secara fisik, anak sedang mengembangkan keterampilan motorik halus yang diperlukan untuk menggunakan otot-otot di jarijarinya dan tangan untuk menulis dan menggambar.

Berdasarkan beberapa pendapat di atas, maka dapat disimpukan bahwa kemampuan menulis merupakan kesanggupan dalam membuat coretan dan pola garis dalam bentuk kata, huruf atau simbol gambar untuk mengekspresikan pikiran pada permukaan kertas atau pada permukaan yang lainnya dengan menggunakan pensil atau pena yang membutuhkan koordinasi mata dan tangan.

\section{b. Tahapan-tahapan Kemampuan menulis Anak usia 5-6 tahun}

Tahapan-tahapan kemampuan menulis anak mengikuti perkembangan berdasarkan kemampuan dan usia anak. Oleh karena itu perlu diperhatikan tahapan perkembangan kemampuan menulis pada anak. Dengan demikian dapat diberikan stimulus yang tepat dan sesuai dengan kemampuan anak. Menurut Sulzby yang dikutip Musfiroh, menjelaskan bahwa tahapan anak dibagi menjadi 6 tahapan, yaitu: 1) Tahap mencoret dan menggores (scribble stage); 2) Tahap pengulangan linear (linear repetitive stage); 3) Tahap huruf acak 
(random letter stage); 4) Tahap menulis fonetik (phonetic writing stage); 5) Tahap eja transisi (transitional speling stage); 6) Tahap eja konvensional (convensional spelling stage).(Musfiroh, 2009)

1) Tahap mencoret dan menggores (scribble stage)

Pada tahap ini anak mulai membuat coretan. Bagi anak, coretan itu adalah sebuah tulisan yang bermakna. Pada tahap ini, tulisan guru dan orng tua sangat dibutuhkan sebagai model menulis bagi anak.

2) Tahap pengulangan linear (linear repetitive stage)

Pada tahap ini anak menulis dengan bentuk linear dan menangkap kesan bahwa kata-kata ada yang terbentuk panjang dan ada pula yang pendek. Kata-kata itu diwujudkan dalam garis bergelombang panjang atau pendek. Pada tahap ini anak membutuhkan dukungan sehingga garis-garis bergelombang itu mulai membentuk huruf-huruf.

3) Tahap huruf acak (random letter stage)

Pada tahap ini anak mulai menuliskan huruf-huruf walaupun bukan kata-kata yang konvensional, tetapi bagi mereka adalah kata-kata.dua huruf yang dijajar mungkin bermakna kata yang sangat berbeda dengan betuknya.

4) Tahap menulis fonetik (phonetic writing stage)

Pada tahap ini anak mulai menghubungkan betuk tulisan dengan bunyinya. Tahap ini disebut tshsp menulis nama huruf (letter name writing) karena anak menuliskan huruf-huruf yang namanya dan bunyinya sama.

5) Tahap eja transisi (transitional speling stage)

Pada tahap ini anak mulai belajar tentang system tulisan yakni bahasa tulis yang konvensional. Anak mulai melafalkan hurufhuruf dalam rangkaian kata secara konvensional.

6) Tahap eja konvensional (convensional spelling stage)

Pada tahap ini anak dapat menulis dengan bentuk yang konvensional.

Menurut Morrow yang dikutip oleh Dhini menyatakan bahwa kemampuan menulis terdiri dari 6 tahapan, antara lain: 1) Menulis lewat gambar (writing via drawing); 2) Menulis lewat goresan (writing via scribbling); 3) Menulis dengan membuat bentuk seperti huruf (writing via making letter-like form); 4) menghasilkan tulisan dengan mencontoh bentuk yang sudah ada (writing via reproducing well-learned unit or letter stings); 5) menulis dengan mengeja satu persatu (writing via interved spelling); 6) Menulis dengan mengeja secara benar (writing via conventional spelling).(Dhini, n.d.). Selanjutnya Feldman memberikan 
tahapan kemampuan menulis anak dimulai dari : 1) Scribble on the page (membuat goresan pada kertas; 2) Copy Word (menjiplak huruf) 3) Invented Spelling (belajar mengeja dan menuliskan huruf sesuai dengan suaranya).(Jean R. Feldman, 1993)

Berdasarkan beberapa pendapat ahli di atas mengenai tahapan kemampuan menulis, dapat disimpulkan bahwa tahapan dimulai dari yang paling sederhana sampai ke tahapan yang paling tinggi. Kemunculan potensi kemampuan menulis dapat ditandai oleh perilaku-perilaku ketertarikan pada kegiatan menulis seperti mulai senang mencoret-coret, menulis huruf ciptaannya, mulai menulis nama sendiri, mulai meniru tulisan dan lain sebagainya.

\section{c. Faktor-faktor yang mempengaruhi kemampuan menulis}

Kemampuan menulis merupakan kegiatan yang kompleks, artiya banyak faktor yang mempengaruhinya. Menurut Learner yang dikutip Samsiah terdapat beberapa faktor yang mempengaruhi kemampuan anak menulis, antara lain:(Samsiah, 2008)

a) Motorik

Anak yang perkembangan motoriknya belum matang atau mengalami gangguan.

b) Persepsi

Anak yang mengalami gangguan persepsi visual yang terganggu akan sulit membedakan bentuk-bentuk huruf yang hampir sama.

c) Memori

Anak yang mengalami gangguan memori visual anak sulit mengingat huruf atau kata.

d) Kemampuan melaksanakan Cross Modal

Kemampuan mentransfer dan mengorganisasikan fungsi visual ke motorik.

e) Penggunaan tangan yang dominan

Anak yang menggunakan tangan kidal terkadang terbalik-balik dalam penulisan.

f) Kemampuan memahami instruksi

Ketidakmampuan memahami instruksi dapat menyebabkan anak sering keliru menulis kata-kata yang sesuai dengan perintah guru.

Menurut Munawir, faktor yang dapat mempengaruhi anak dalam kesulitan menulis, yaitu: 1) Gangguan motorik; 2) Gangguan emosi; 3) Gangguan persepsi visual; 4) Gangguan ingatan.(Yusuf, 2005)

\section{Hakikat Permainan Menggambar}




\section{a. Definisi Permainan}

Bagi anak bermain adalah dunianya, selain itu bermain juga merupakan hak anak-anak. Pendapat orang tua saat ini adalah dengan belajar anak bisa menjadi pintar, dan terlalu sering bermain membuat anak tidak bisa menjadi pintar. Memang pendapat ini ada benarnya jika kita melihat dari sisi kemampuan membaca, menulis, dll.

Bermain adalah aktivitas yang dipilih sendiri oleh anak dan sebagai media untuk melatih kemampuannya.(Semiawan, 2008) Tujuan bermain adalah memberi kesenangan sekaligus mengembangkan aspek perkembangan. Jika para orang tua terlalu memaksakan kehendaknya sendiri tanpa memperdulikan kehendak anak, maka tujuan tersebut tidak akan tercapai.

Dalam bukunya "Teaching Young Development", Henniger mengutip pernyataan Dewey bahwa bermain terdiri dari kegiatan yang tidak sadar dilakukan untuk menghasilkan sesuatu yang diluar hasil yang anak-anak bayangkan.(Henniger, 2013). Ketika anak-anak bermain, mereka melakukannya proses yang berarti bagi mereka dengan kegiatan yang memberikan nilai. Jika ada hasil akhir, itu akan memiliki sedikit makna bagi anak.

Menurut Stone, bermain merupakan media penting untuk proses berpikir.(Stone, 1993). Permainan merupakan suatu hal yang menyenangkan bagi anak. Pada saat anak bermain semua benda dapat dijadikan objek permainan, secara sadar atau tidak sadar ia belajar dari sifat-sifat objek tersebut. Melalui bermain, anak memiliki rasa percaya diri dan harga diri. Dia akan berusaha melepaskan ketegangan yang dialaminya melalui permainan yang dilakukannya. Anak belajar untuk berinteraksi dengan orang lain, menjalin hubungan dengan teman sebaya, belajar berbagi, mempertahankan hubungan, pemecahan masalah bahkan juga belajar berpisah dari ibu atau pengasuhnya.

Dari beberapa pendapat para ahli di atas dapat disimpulkan bahwa permainan adalah suatu pola kegiatan yang mendatangkan kesenangan untuk anak yang dapat dijadikan pengalaman berimajinasi dan berkreasi sehingga anak mampu mengekspresikan hal-hal yang didapatkan dalam suatu permainan. Kegiatan bermain juga merupakan bagian mutlak dari kehidupan anak dan permainan merupakan bagian integral dari proses pembentukan kepribadian anak.

\section{b. Definisi Menggambar}

Menggambar merupakan wujud pengeksplorasian teknis dan gaya, penggalian gagasan dan kreativitas bahkan menjadi ekspresi dan 
aktualisasi diri. Melalui kegiatan menggambar, motorik halus anak dilatih dan akan sangat bermanfaat ketika anak harus menulis di usia sekolahnya nanti. Menggambar merupakan aktivitas yang menyenangkan bagi anak bahkan mulai usia dini, anak sudah senang mencorat coret di buku, dinding atau dimanapun yang anak-anak inginkan. Aktivitas menggambar ini akan bermanfaat bagi otak dan fisik anak dan sudah seharusnya aktivitas kegemaran ini diberi fasilitas yang baik.

Brittain mengungkapkan bahwa saat menggambar anak usia prasekolah adalah lebih banyak mengekspresikan dirinya. Menggambar untuk mereka bukan berupa catatan di masa lalu atau representasi visual masa kini seperti yang diharapkan dari sebuah foto, juga bukan pemenuhan keinginan dari anak tersebut.(Brittain. W. Lambert, 1987)

Selanjutnya Capon mendefinisikan menggambar merupakan suatu kegiatan yang informatif berbentuk ekspresif dan dekoratif, dimana dapat bersifat menghibur, serius dan intelektual.(Capon, 2001) Ketika seorang anak sedang menggambar, anak tersebut sedang menyampaikan informasi baik dalam bentuk ekspresif maupun dekoratif. Gambar yang dihasilkannya bisa bersifat menghibur dan dapat juga bersifat serius yang mengandung unsur-unsur intelektual.

Hal ini juga ditegaskan Alam hudi bahwa menggambar pada dasarnya adalah proses untuk mengekspresikan sesuatu yang terpendam di dalam jiwa lewat media tertentu.(Alamhudi, 2000) Jadi dengan menggambar, anak-anak akan bebas berekspresi sesuai kemampuan dan keinginan anak-anak baik saat perasaan mereka senang ataupun sedih.

Selanjutnya menurut Hamzah dan Nugraha, menggambar merupakan suatu kegiatan yang menyangkut penciptaan wujud yang terdiri dari perpaduan garis, bidang, bentuk dan warna pada suatu bidang datar dengan menggunakan segala macam alat dan bahan yang ada.(Nugraha., 2000). Dengan kegiatan menggambar, anak yang dibebaskan berekspresi akan menuangkan ide kreatifnya dengan perpaduan berbagai garis, bidang, bentuk dan perpaduan warna hingga menjadi lebih menarik. Pada intinya menggambar adalah perpaduan keterampilan, kepekaan rasa, kreativitas, ide, pengetahuan dan wawasan.

Patmonodewo mengemukakan bahwa anak sudah dapat membuat gambar orang yang biasanya ditunjukkan dengan lingkaran besar, yaitu kepala kemudian ditambahakan bulat kecil sebagai mata, hidung, mulut dan telinga, kemudian ditarik garis-garis dengan 
maksud menggambar badan, kaki dan tangan. (Patmonodewo, 2003) Jadi anak usia 5-6 tahun dapat menggunakan gambar sebagai ungkapan dalam berkomunikasi dengan orang lain. Selain itu juga koordinasi tangan dan mata berkemang dengan pesat sehingga anak dapat menciptakan gambar yang sesuai dengan lingkungan yang mereka senangi.

Tujuan dari menggambar dikemukakan Sudono, yaitu mengembangkan kebiasaan pada anak untuk mengekspresikan diri, mengembangkan daya kreativitas, mengembangkan kemampuan berbahasa, mengembangkan citra diri anak. Dari pendapat diatas dapat dikatakan bahwa tujuan dari kegiatan menggambar adalah sarana pengembangan ide, kreativitas, percaya diri, kemampuan berbahasa anak.

Dari beberapa pendapat di atas, dapat disimpulkan bahwa menggambar adalah suatu kegiatan yang merupakan ekspresi dan bagian dari proses kreatif dan imajinatif. Dengan menggambar, anak akan belajar mencipta atau berkreasi, anak belajar mengungkapkan siapa dirinya, bebas mengungkapkan ide, pikiran dan gagasan, menggambar sesuai dengan caranya sendiri tanpa takut salah hingga anak menghasilkan keunikan-keunikan dirinya, belajar mengenal siapa dirinya.

\section{c. Tahapan menggambar Anak Usia 5-6 Tahun}

Pada usia 5-6 tahun anak masih terpengaruh pada tahapan menggambar corat-coret, sehingga guru dan orang tua harus bisa mengarahkan kegiatan menggambar anak yang menyenangkan dan kreatif. Pada tahapan menggamba anak akan lebih tertarik pada pemilihan warna yang sesuai dengan keinginan hati anak, karena hasil gambar anak pada tahapan awal ini akan bersifat ekspresif dan dinamis.

Tahapan menggambar pada anak usia 5-6 tahun merupakan masa awal atau praskema, pada anak usia ini kegiatan menggambar merupakan kegiatan yang menyenangkan. Dengan menggambar akan menjadi sebuah pengalaman yang menakjubkan bagi anak usia 5-6 tahun dengan konsep realitas dalam sebuah seni termunculkan.(W., 1993)

Pada awalnya anak hanya mengenal bentuk-bentuk abstrak dan coretan sederhana jauh dari bentuk asli ketika mereka berada pada usia di bawah lima tahun, namun berbeda ketika mereka sudah memasuki usia 5-6 tahun, anakanak sudah memiliki objek gambar yang hampir menyerupai bentuk aslinya. 
Peningkatan Kemampuan Menulis Melalui Permainan Menggambar (Penelitian Tindakan di Kelompok B Taman Kanak-Kanak Sos Desa Taruna Jakarta Timur)

Ini pun tidak terlepas dari anak yang selalu diberikan stimulasi menggambar dengan baik sesuai dengan kematangan perkembangan anak itu sendiri.

\section{HASIL DAN PEMBAHASAN}

\section{Hasil}

Pada bagian pendahuluan telah diuraikan bahwa ada dua tujuan penelitian tindakan peningkatan kemaampuan menulis melalui permainan menggambar adalah untuk memahami proses dalam meningkatkan kemampuan menulis pada anak kelompok B di TK SOS Desa Taruna Jakarta Timur melalui permainan menggambar dan untuk mengetahui peningkatan kemampuan menulis pada anak kelompok B di TK SOS Desa Taruna Jakarta Timur melalui permainan menggambar.

Kemampuan menulis terdiri dari mampu menghasilkan tulisan dengan cara membuat bentuk, mampu menghasilkan tulisan dengan cara membuat simbol sederhana, mampu menghasilkan tulisan dengan cara menyalin nama, mampu menghasilkan kata sederhana. Hasil penelitian kemampuan awal tindakan yang telah dilakukan oleh peneliti, menjelaskan bahwa kemampuan menulis di TK SOS Desa Taruna ini masih rendah, karena sebagian besar anak masih belum bisa membuat bentuk-bentuk atau simbol-simbol sederhana, menulis angka, huruf dan kata, serta belum bisa menuliskan nama depan anak sendiri.

Berikut merupakan tabel Kemampuan awal menulis Kelompok B TK SOS Desa Taruna, Jakarta-Timur :

Tabel 1. Data Kemampuan Awal Menulis

\begin{tabular}{clcc}
\hline NO & NAMA ANAK & SKOR & PRESENTASE $\%$ \\
\hline 1 & CAK & 22 & $37 \%$ \\
\hline 2 & TIA & 20 & $33 \%$ \\
\hline 3 & ENZ & 23 & $38.30 \%$ \\
\hline 4 & DEV & 22 & $37 \%$ \\
\hline 5 & SAM & 22 & $37 \%$ \\
\hline 6 & RUB & 24 & $40 \%$ \\
\hline 7 & DEW & 22 & $37 \%$ \\
\hline 8 & NAT & 23 & $38.30 \%$ \\
\hline 9 & ASH & 20 & $33 \%$ \\
\hline 10 & ANG & 22 & $37 \%$ \\
\hline \multicolumn{4}{r}{ RATA-RATA KELAS } \\
\hline
\end{tabular}




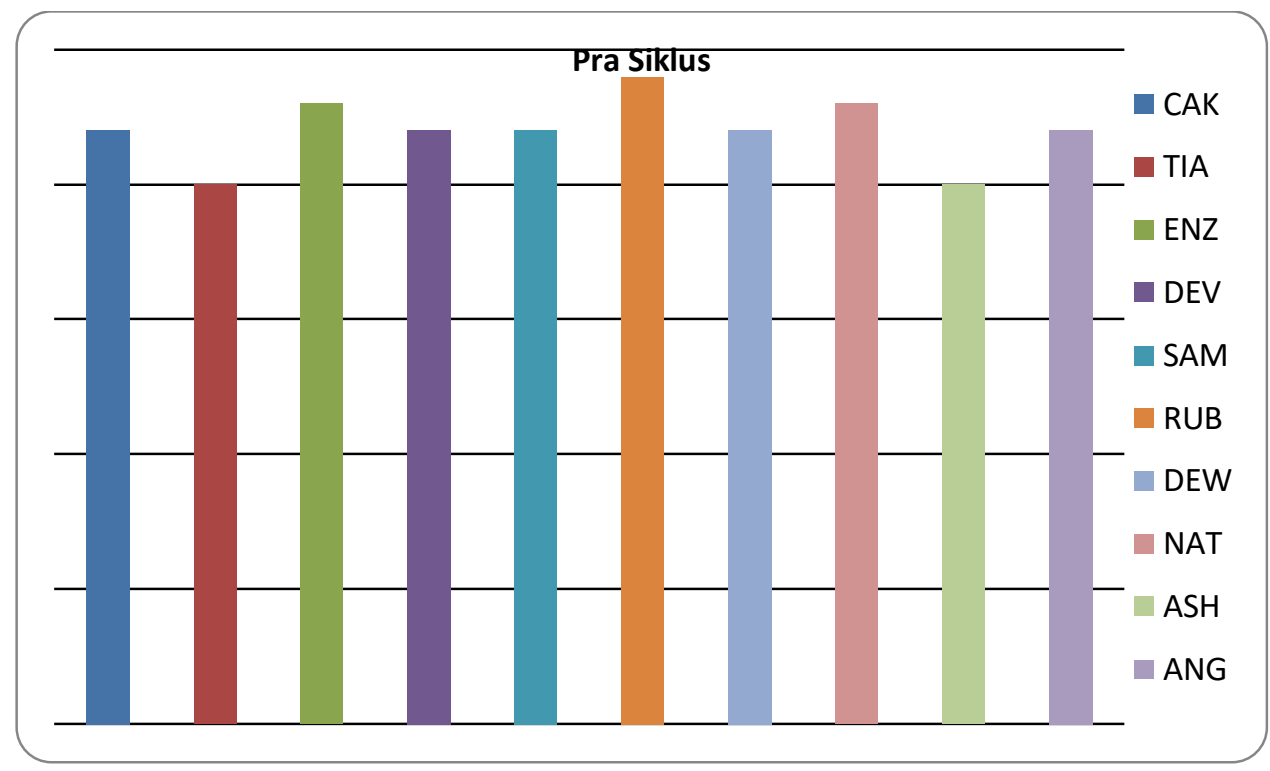

Gambar 1. Grafik skor pra tindakan kemampuan menulis

Berdasarkan data prosentase diatas maka dapat diperoleh hasil dari penelitian awal (pra tindakan) kemampuan menulis, CAK memperoleh $37 \%$ dalam kemampuan menulis, TIA memperoleh $33 \%$ dalam kemampuan menulis, ENZ memperoleh $38.3 \%$ dalam kemampuan menulis, DEV memperoleh 37\% dalam kemampuan menulis, SAM memperoleh 37\% dalam kemampuan menulis, RUB memperoleh $40 \%$ dalam kemampuan menulis, DEW memperoleh 37\% memperoleh $37 \%$ dalam kemampuan menulis, NAT memperoleh $38.3 \%$ dalam kemampuan menulis, ASH memperoleh 33\% dalam kemampuan menulis, ANG memperoleh 37\% dalam kemampuan menulis.

Dari hasil observasi terhadap implementasi tindakan pada siklus I, selama kegiatan berlangsung, peneliti dan kolaborator mengamati jalannya kegiatan untuk melihat apakah kegiatan yang dilaksanakan sesuai dengan rencana. Hasil pengamatan peneliti dan kolaborator menunjukkan bahwa pelaksanaan tindakan yang dilakukan sudah sesuai dengan rencana. Penemuan yang dilihat pada siklus I adalah anak-anak senang, bersemangat dan antusias mengikuti pembelajaran menulis melalui permainan menggambar, karena anak-anak bebas mengekspresikan pikirannya ke dalam coretan bergambar dan juga coretan yang berwarna.

Berikut ini adalah hasil dari penilaian skor siklus I, yang ditunjukkan pada bagan berikut ini. 
Peningkatan Kemampuan Menulis Melalui Permainan Menggambar (Penelitian Tindakan di Kelompok B Taman Kanak-Kanak Sos Desa Taruna Jakarta Timur)

Tabel 2. Tabel Skor Siklus I Kemampuan Menulis

\begin{tabular}{clcc}
\hline NO & NAMA ANAK & SKOR & PROSENTASE \% \\
\hline 1 & CAK & 38 & 63.30 \\
\hline 2 & TIA & 38 & 63.30 \\
\hline 3 & ENZ & 39 & 65 \\
\hline 4 & DEV & 39 & 65 \\
\hline 5 & SAM & 39 & 65 \\
\hline 6 & RUB & 39 & 65 \\
\hline 7 & DEW & 40 & 67 \\
\hline 8 & NAT & 39 & 65 \\
\hline 9 & ASH & 39 & 65 \\
\hline 10 & ANG & 38 & 63.30 \\
\hline & RATA-RATA KELAS & 38.8 & $64.69 \%$
\end{tabular}

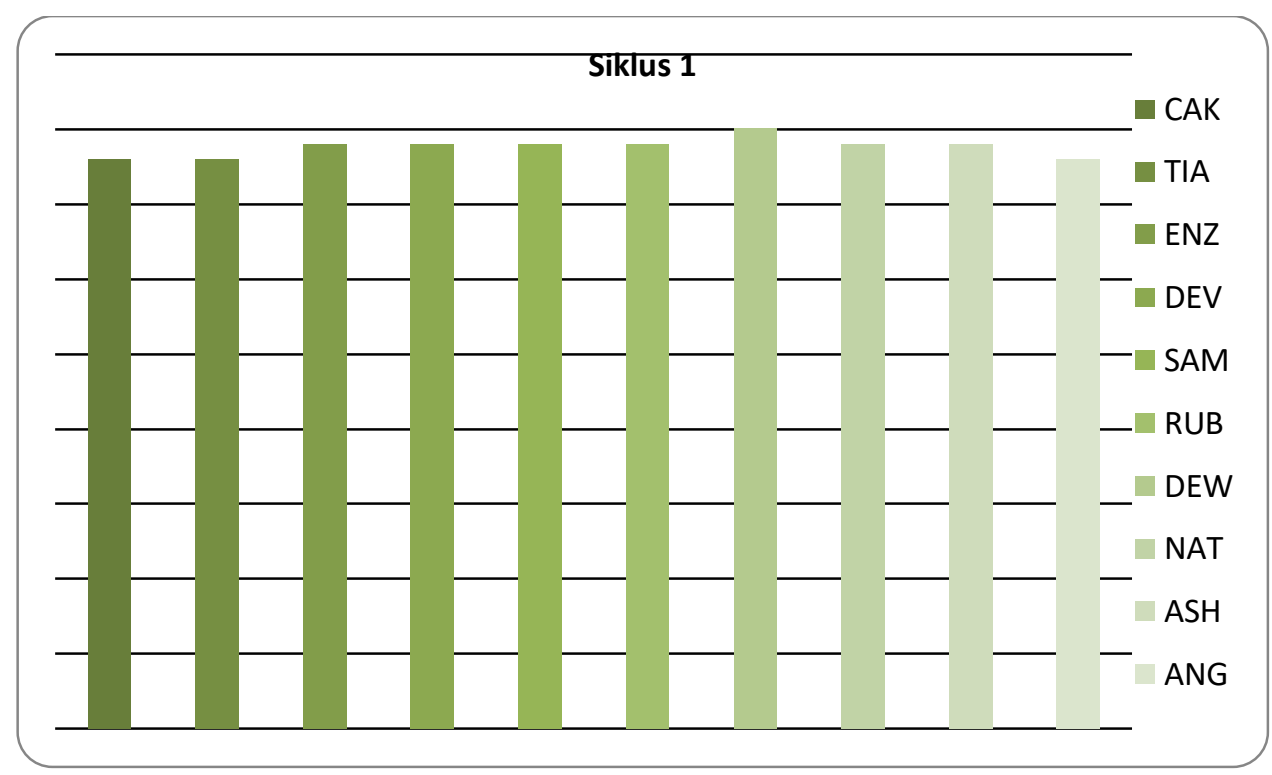

\section{Gambar 2. Grafik Skor Siklus I Kemampuan Menulis}

Menindaklanjuti dari siklus I ke siklus II agar prosentase mencapai keberhasilan peneliti dan kolaborator sudah mempersiapkan kegiatan yang perlu dilakukan di siklus II sesuai dengan refleksi yang sudah diperbaiki agar di siklus II ini kemampuan menulis pada kelompok B TK SOS Desa Taruna dapat lebih meningkat. Pada kegiatan di siklus II dilaksanakan beberapa tahap-tahap sebagai berikut:

Hasil pengamatan peneliti dan kolaborator pada kegiatan di siklus II ini adalah secara keseluruhan terjadi peningkatan dalam 
kemampuan menulis kelompok B TK SOS Desa Taruna dari awal kegiatan pra-tindakan, siklus I, hingga siklus II. Peningkatan ini disebabkan oleh pembiasaan kegiatan yang sering dilakukan, bertambahnya kegiatan untuk meningkatkan kemampuan menulis, dan antusias anak-anak yang selalu semangat saat melakukan permainan menggambar. Dari delapan kali pertemuan dengan permainan menggambar untuk meningkatkan kemampuan menulis pada kelompok B di TK SOS Desa Taruna dapat dilihat dari hasil penjabaran nilai anak dalam kegiatan anak di siklus II adalah sebagai berikut.

Tabel 3. Tabel Skor Siklus II Kemampuan Awal Menulis

\begin{tabular}{clcc}
\hline NO & NAMA ANAK & SKOR & PROSENTASE $\%$ \\
\hline 1 & CAK & 54 & $90 \%$ \\
\hline 2 & TIA & 53 & $88.33 \%$ \\
\hline 3 & ENZ & 54 & $90 \%$ \\
\hline 4 & DEV & 53 & $88.33 \%$ \\
\hline 5 & SAM & 52 & $87 \%$ \\
\hline 6 & RUB & 55 & $91.67 \%$ \\
\hline 7 & DEW & 52 & $87 \%$ \\
\hline 8 & NAT & 53 & $88.33 \%$ \\
\hline 9 & ASH & 53 & $88.33 \%$ \\
\hline 10 & ANG & 53 & $88.33 \%$ \\
\hline \multicolumn{2}{r}{ RATA-RATA KELAS } & 53.2 & $88.73 \%$ \\
\hline
\end{tabular}

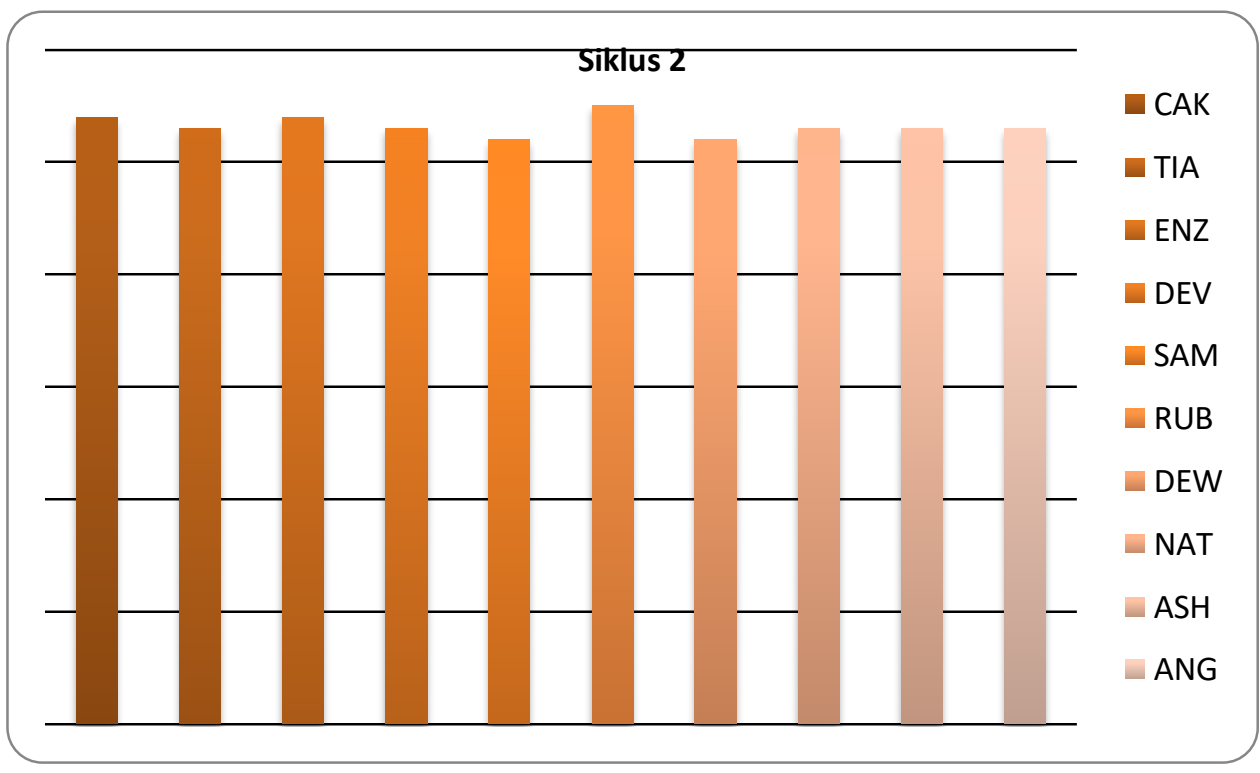

Gambar 3. Grafik Skor Siklus II Kemampuan Menulis

JECIES: Journal of Early Childhood Islamic Education Study

Vol. 01, Nomor 02, September 2020 
Peningkatan Kemampuan Menulis Melalui Permainan Menggambar (Penelitian Tindakan di Kelompok B Taman Kanak-Kanak Sos Desa Taruna Jakarta Timur)

\section{CONCLUSION}

Berdasarkan pertanyaan dari rumusan masalah pada pendahuluan, maka dapat diambil kesimpulan dari penelitian tindakan ini adalah sebagai berikut:

1. Proses pembelajaran berawal dari (a) Peneliti bersama kolaborator menentukan rencana kegiatan pembelajaran tentang kemampuan menulis melalui permainan menggambar; (b) Menyediakan perangkat permainan menggambar yang digunakan dalam pembelajaran; (c) Menyiapakan alat yang akan digunakan sebagai alat pengumpulan data berupa catatan lapangan, lembar observasi (instrument penilaian kemampuan menulis) dan alat dokumentasi; (d) Guru menunjukkan dan menjelaskan kepada anak-anak media permainan menggambar; (e) Guru mempraktekkan permainan menggambar dan diikuti anakanak dengan mempraktekkan langsung permainan menggambar; ( $f$ ) Guru memfokuskan untuk meningkatkan kemampuan anak untuk mampu menghasilkan tulisan dengan cara membuat bentuk, mampu menghasilkan tulisan dengan cara membuat simbol sederhana, mampu menghasilkan tulisan dengan cara menyalin nama, mampu menghasilkan kata sederhana; (g) Guru mengulang permainan menggambar sampai anak memahami dan terjadi peningkatan kemampuan menulis; (h) Evaluasi dilakukan dengan observasi, pengamatan dan juga beberapa wawancara.

2. Kemampuan menulis pada kelompok B di TK SOS Desa Taruna Jakarta Timur mengalami peningkatan setelah melakukan permainan menggambar yang dibuktikan dengan peningkatan prosentase pada setiap aspek yaitu kemampuan menulis saat pra tindakan mencapai $36.76 \%$. \%, setelah dilaksanakan siklus I meningkat menjadi $64.4 \%$. dan pada siklus II meningkat lagi menjadi $88.73 \%$. Peningkatan prosentase yang terjadi di atas menandakan bahwa dengan permainan menggambar yang telah dilakukan dapat meningkatkan kemampuan menulis kelompok B TK SOS Desa Taruna. Semua data diolah dan disatukan untuk mengumpulkan bukti bahwa permainan menggambar ini dapat meningkatkan kemampuan menulis yang dilihat dari hasil observasi peneliti menunjukkan bahwa terdapat perubahan pada anak-anak dalam pembelajaran menulis yang mulanya masih terlihat kaku dalam membuat coretan menjadi lancar dalam mengekspresikan tulisan sederhananya. Setelah diadakan perhitungan skor dan reduksi data, maka dapat disimpulkan bahwa permainan menggambar dapat meningkatkan kemampuan menulis kelompok B TK SOS Desa Taruana Jakarta Timur. 


\section{DAFTAR PUSTAKA}

Alamhudi, Firdaus. Feather Painting. Yogyakarta: Adicipta Karya Nusa, 2000.

Arikunto, Suharsimi. Penelitian Tindakan Kelas. Jakarta: Bumi Aksara, 2008.

Beaty, Janice J. Observing Development of the Young Child, Seventh Edition. Missourri, 2010.

Brewer, Jo Ann. Introduction Early Childhood Education, Preschool through Primary Grades, Sixth Edition. USA: Pearson Education, 2007.

Capon, Robin. Drawing. USA: MC. Graw Hill, 2001.

Catron, Carol E., and Jan Allen. Early Childhood Curriculum A CreativePlay Model, Second Edition. USA: Prentice-Hall, Inc, 1999.

Departemen Pendidikan Nasional. Acuan Menu Pembelajaran pada Pendidikan Anak Usia Dini, Menu Pembelajaran Generik. Jakarta: Dirjen PLS, 2002.

Dhini, Nurbiana, Modul Metode Pengembangan Bahasa. Jakarta: Pusat Penerbitan UT.

Dockett, Sue, and Marilyn Fleer. Play and Pedagogy in Early Childhood Bending the Rules. Sdney: Harcourt, 2000.

Eliason, Claudia, and Loa Jenkins. A Practical Guide to Early Childhood Curriculum. Ohio: Pearson Prentice Hall, 2008.

Feldman, Jean R. A Survival Guide for Preschool Teacher. New York: The Center for Applied Research In Education, 1993.

Hamzah, R. ,dan Onong Nugraha. Pengetahuan Dasar Kegiatan Seni Rupa. Jakarta: PT Mutiara Sumber Widya, 2000.

Handini, Myrnawati Crie. Metodologi Penelitian Untuk Pemula. Jakarta : FIP Press.

Henniger, Michael L. Teaching Young Children, Fifth Edition. Upper Saddle River NJ: Pearson Education, 2013.

Hurlock, Elizabeth. Perkembangan Anak, Edisi Keenam Jilid 1. Jakarta: Erlangga, 1978.

------. Psikologi Perkembangan, Edisi Kelima. Jakarta: Erlangga, 1980.

Jackman, Hilda L. Early Education Curriculum, A Child's Connection to The World, Fifth Edition. USA: Wadsworth, 2012

Jalongo, Mary Renck. Early Childhood Language Arts, Fourth Edition . USA: Pearson Education Inc, 2007.

Janet, Moyles R. The Exellence of Play. USA:Bristol, 1994.

Joanne, Hendrick. The Whole Child Development Education for The Early Years. New Jersey, 2001.

Mertler, Craig A. Action Research "Mengembangkan Sekolah dan Memberdayakan Guru”. Yogyakarta: Pustaka Pelajar, 2011.

JECIES: Journal of Early Childhood Islamic Education Study

Vol. 01, Nomor 02, September 2020 
Peningkatan Kemampuan Menulis Melalui Permainan Menggambar (Penelitian Tindakan di Kelompok B Taman Kanak-Kanak Sos Desa Taruna Jakarta Timur)

Mills, Geoffrey E. Action Research, A Guide For The Teacher Researcher, Second Edition. USA: Merrill Prentice Hall, 2003.

Morrison, George S. Dasar-dasar Pendidikan Anak Usia Dini, Edisi kelima. Jakarta: Indeks, 2012.

Mulyasa, E. Manajemen Pendidikan Anak Usia Dini. Bandung: Remaja Rosdakarya, 2012.

Musfiroh, Tadkiroatun. Menumbubkan Baca Tulis Anak Usia Dini. Jakarta: Gramedia, 2009.

Papalia, Diane E., Sally W. Odds, dan Ruth Duskin Feldman. Human Development, Edisi 10. Jakarta: Salemba Humanika, 2008.

Program Pascasarjana Universitas Negeri Jakarta. Buku Pedoman Penulisan Tesis dan Disertasi. Jakarta, 2012.

Rahandoko,Ndaru. Tebnik Dasar Menggambar Untuk Anak. Depok: PT Kawan Pustaka, 2008.

Santrock, John W. Psikologi Pendidikan (Educational Psychology), Edisi Kedua. Jakarta:Kencana, 2004.

2007.

-----. Perkembangan Anak, Edisi Kesebelas Jilid 1. Jakarta: Erlangga,

Samsiah. Buku Ajar Kesulitan Calistung pada Anak Usia Dini. Jakarta: Cahaya Mentari Nasution, 2008.

Santoso, Soegeng. Dasar-dasar Pendidikan Anak TK Edisi Kesatu. Jakarta: Universitas Terbuka, 2005.

-----. Pendidikan Anak Usia Dini. Jakarta: Citra Pendidikan, 2002.

-----. Konsep Dasar Pendidikan Anak Usia Dini, Pidato yang disampaikan pada Pendidikan dan Pelatihan Bagi Pendidik PAUD tanggal 25 Januari 2010 di Bantul, Yogyakarta.

Seefeld, Carol dan Barbara A. Wasik. Pendidikan Anak Usia Dini Edisi Kedua. Jakarta: Indeks, 2008.

Semiawan, Conny R. Belajar dan Pembelajaran Prasekolah dan Sekolah Dasar. Jakarta: Indeks, 2008.

Siegler, Robert S dan Martha Wagner Alibali. Cbildrens Thinking, Fourth Edition. Prentice-Hall, Inc. New Jersey: Upper Saddle River, 2005.

Sonawat, Reeta dan Jasmine Maria Francis, Language Development for Preschool Children. Mumbai: Multi-tech Publishing, 2007.

Sugiyono. Metodologi Penelitian Kualitatif, Edisi Revisi. Bandung: CV Alfabeta, 2005.

Suryanto, Slamet. Pendidikan Anak Usia Dini. Jakarta: Depdiknas, 2003.

Suyadi. Psikologi Belajar PAUD. Yogyakarta: Pedajogja, 2010.

Sudono, Anggani. Sumber Belajar dan Alat Permainan (untuk PAUD). Jakarta: Grasindo, 2000. 
Trianto, Panduan Lengkap Penelitian Tindakan Kelas, Classroom Action Research, Teori dan Praktik. Jakarta: Prestasi Pustakaraya,2011.

Undang-undang RI Nomor 20 Tahun 2003 Tentang Sistem Pendidikan Nasional.

Wiriatmadja, Rochiati. Metode Penelitian Tindakan Kelas. Bandung: Remaja Rosdakarya, 2005.

Yus, Anita. Penilaian Perkembangan Belajar Anak Taman Kanak-kanak. Jakarta: Kencana, 2011.

Yusuf, Munawir. Pendidikan Bagi Anak Dengan Problema Belajar. Jakarta: Depdiknas, 2005. 